Check for updates

Cite this: J. Mater. Chem. A, 2018, 6, 3977

Received 27th December 2017 Accepted 26th January 2018

DOI: 10.1039/c7ta11308k

rsc.li/materials-a

\section{Interdigitated back-contacted crystalline silicon solar cells with low-temperature dopant-free selective contacts $\dagger$}

\author{
G. Masmitjà, (D)* P. Ortega, (D) J. Puigdollers, (D) L. G. Gerling, (D) I. Martín, (D) C. Voz (D) \\ and R. Alcubilla
}

In the field of crystalline silicon solar cells, great efforts are being devoted to the development of selective contacts in search of a fully low-temperature and dopant-free fabrication process compatible with high photovoltaic conversion efficiencies. For high-efficiency devices, selective contacts have to simultaneously combine high conductivity with excellent passivating properties. With this objective, a thin passivating extra layer of a-Si: $\mathrm{H}$ or $\mathrm{SiO}_{2}$ is usually introduced between the conducting layer and the silicon substrate. In this work, we present an interdigitated back-contacted (IBC) silicon based solar cell that avoids the use of either thermal $\mathrm{SiO}_{2}$ or a-Si:H interlayers achieving a dopant-free, ITO-free and very low thermal budget fabrication process. In this work, we propose a new electron transport layer using ultrathin $\mathrm{Al}_{2} \mathrm{O}_{3} / \mathrm{TiO}_{2}$ stacks deposited by atomic layer deposition at $100{ }^{\circ} \mathrm{C}$ covered with a thermally evaporated $\mathrm{Mg}$ capping film. A specific contact resistance of $2.5 \mathrm{~m} \Omega \mathrm{cm}^{2}$ has been measured together with surface recombination velocities below $40 \mathrm{~cm} \mathrm{~s}^{-1}$. This electron-selective contact is combined with a thermally evaporated $\mathrm{V}_{2} \mathrm{O}_{x}$-based hole selective contact to form the rear scheme of an IBC structure with a $3 \times 3 \mathrm{~cm}^{2}$ active area as a proof-of-concept resulting in efficiencies beyond $19 \%$. This approach sheds light on potential technological simplification and cost reduction in crystalline silicon solar cells.

\section{Introduction}

Highly selective contacts to one type of carrier, i.e. passivated contacts, are necessary for high-efficiency solar cells. The function of such contacts is to block totally (ideally) or partially (in practice) one type of carrier, electrons or holes, while the other one is collected. ${ }^{1}$ Nowadays, the photovoltaic industry is mainly dominated by crystalline silicon (c-Si) solar cells, in which contact selectivity is usually achieved by doping the wafer surfaces with phosphorus $\left(\mathrm{n}^{+}\right)$and boron $\left(\mathrm{p}^{+}\right)$by means of high temperature oven-based diffusions, increasing either electron or hole conductivity. In this way, $\mathrm{p}^{+} \mathrm{nn}^{+}$and $\mathrm{n}^{+} \mathrm{pp}^{+}$doping schemes are a common way of achieving contact selectivity with n or p-type substrates, respectively. However, doping needs to be performed at high temperatures, requiring complex and energy consuming processes and lengthy cleaning protocols to avoid possible degradations of bulk lifetime, increasing the number of steps involved in the fabrication process and consequently the cost.

Department of Electronic Engineering, Universitat Politècnica de Catalunya (UPC), c/Jordi Girona 1-3, Mòdul C-4, 08034 Barcelona, Spain. E-mail: gerard.masmitja@ upc.edu

$\dagger$ Electronic supplementary information (ESI) available. See DOI: $10.1039 / \mathrm{c} 7 \mathrm{ta} 11308 \mathrm{k}$
In order to replace those high temperature diffusions, several approaches have been studied. The well-known silicon heterojunction (SHJ) structure using doped and intrinsic hydrogenated amorphous silicon (a-Si:H) films is probably the best known and combined with an interdigitated back-contacted (IBC) cell architecture holds the world efficiency record on c-Si substrates. ${ }^{2}$ Another low-temperature technology proposed is laser-doping where the $\mathrm{p}^{+}$and $\mathrm{n}^{+}$regions are formed by laser-processing of dielectric films., ${ }^{3,4}$ Nevertheless, both options use toxic and flammable gases as dopant precursors, which is not desirable from the point of view of process complexity.

A possible alternative arises from the heritage of thin film and organic photovoltaics, where novel materials are routinely used as semipermeable membranes to selectively extract carriers from a semiconductor light absorber. ${ }^{5}$ In this way, alternative materials that overcome conventional limitations and difficulties have been explored using the so-called DASH approach (Dopant Free Asymmetric Heterocontacts); ${ }^{6}$ materials such as organic polymers (PEDOT:PSS or P3HT), ${ }^{7,8}$ alkaline salts $\left(\mathrm{LiF}_{x}, \mathrm{MgF}_{x}\right.$ or $\left.\mathrm{Cs}_{2} \mathrm{CO}_{3}\right){ }^{6,9,10}$ transition metal oxides (TMOs) ${ }^{11}$ and multilayer $\mathrm{TMO}-$ metal- $\mathrm{TMO}^{12}$ have been successfully applied in c-Si solar cells as hole and electron transport layers (HTL and ETL respectively). This new paradigm broadens the technological possibilities and multiple options are being 
actively explored to achieve the best trade-off between efficiency and simplicity. ${ }^{\mathbf{1 3}}$

In this context TMOs are becoming very attractive because of the combination of wide bandgaps ( $>3 \mathrm{eV}$ ) and consequently high transparency with low temperature deposition techniques, e.g. thermal evaporation, spin-on, spray-on and sputtering. High work-function TMOs $(\sim 7 \mathrm{eV})$ such as molybdenum oxide $\left(\mathrm{MoO}_{x}\right)$, tungsten oxide $\left(\mathrm{WO}_{x}\right)$ and vanadium oxide $\left(\mathrm{VO}_{x}\right)$ are preferred as hole-selective contacts, ${ }^{\mathbf{1 4}}$ while low work-function compounds $(\sim 4 \mathrm{eV})$ such as magnesium oxide $\left(\mathrm{MgO}_{x}\right),{ }^{15}$ lithium fluoride $\left(\mathrm{LiF}_{x}\right)^{6}$ and titanium oxide $\left(\mathrm{TiO}_{x}\right)^{16}$ are being investigated as electron-selective contacts.

Asymmetric conductivity in these materials is achieved either by band alignment or through a strong induced bandbending. In order to take advantage of the band structure of the silicon/contact interface while simultaneously decreasing surface recombination, it is important to avoid Fermi-level pinning by reducing the density of states at the silicon interface. ${ }^{17}$ In most cases, this is achieved by plasma enhanced chemical vapour deposition (PECVD) growth of a thin film of intrinsic a-Si:H between the TMO and the c-Si surface. ${ }^{6}$ Two drawbacks overshadow this approach, the use of flammable gases and the intrinsic difficulty of obtaining good $\mathrm{Si} / \mathrm{a}-\mathrm{Si}: \mathrm{H}$ interfaces. Another possibility is to take advantage of the in situ redox reaction during thermal evaporation of the TMO material which may result in spontaneous growth of a $\mathrm{SiO}_{x}$ film. ${ }^{18,19}$ Finally, some authors,$^{20}$ although introducing a high temperature step, have grown a thin tunnel $\mathrm{SiO}_{2}$ layer between the TMO and the silicon surface.

Regarding electron-selective collector materials, $\mathrm{TiO}_{2}$-based contacts are an interesting alternative. Titania was firstly applied in c-Si photovoltaics as an antireflection coating, ${ }^{21}$ being an alternative to silicon-nitride or silicon oxide films. Recently, $\mathrm{TiO}_{2}$ films have begun to be used as a hole-blocking layer directly making contact with c-Si solar cells. However, poor contact passivation showing effective surface recombination velocities $\left(S_{\text {eff }}\right)$ of around $300 \mathrm{~cm} \mathrm{~s}^{-1}$ has limited the obtained efficiency to $\sim 11 \% .^{22}$ Interface recombination can be drastically reduced by growing an extremely thin thermal $\mathrm{SiO}_{2}$ layer at the interface between silicon and $\mathrm{TiO}_{2}$, where its thickness is the result of a trade-off between contact resistance and passivation. Using this approach for the preparation of the electron-selective contact along with conventional high temperature boron diffusion for the preparation of the holeselective contact, a remarkable efficiency of $21.6 \%$ has been recently obtained for a double-side contacted solar cell. ${ }^{20}$ However, the high value of the contact resistance $\left(>20 \mathrm{~m} \Omega \mathrm{cm}^{2}\right)$ prevents the use of this approach in IBC structures where the electron contact area is only a fraction of the total rear surface.

The replacement of this passivation interlayer, e.g. thermal $\mathrm{SiO}_{2}$ or a-Si:H, by other films, which could be conformably deposited at low temperature with good thickness control, is an important research topic that may drastically simplify the fabrication process and reduce its cost. In this work, we focus on electron-selective contacts made of atomic layer deposited (ALD) $\mathrm{TiO}_{2}$ films combined with an ALD ultrathin $\mathrm{Al}_{2} \mathrm{O}_{3}$ interlayer. The $\mathrm{Al}_{2} \mathrm{O}_{3}$ is introduced between the $\mathrm{TiO}_{2}$ and the silicon surface aiming to reduce the defect density at the interface. In addition to $\mathrm{Al}_{2} \mathrm{O}_{3}$ and $\mathrm{TiO}_{2}$ thicknesses, the influence of different metal capping materials ( $\mathrm{Ni}, \mathrm{Al}$ and $\mathrm{Mg}$ ) has been studied to optimize the selectivity. This $\mathrm{Al}_{2} \mathrm{O}_{3} / \mathrm{TiO}_{2}$ bilayer structure, or a repetition of it in nanolaminates, has been explored in the past for optical or gate dielectric applications. ${ }^{23,24}$ The passivation properties of this stack have been also reported, ${ }^{25}$ but it has not been previously applied and optimized as an electron-selective layer on c-Si solar cells, i.e. simultaneously targeting low surface recombination and contact resistance.

The best contact configuration consisting of a Mg-coated $\mathrm{Al}_{2} \mathrm{O}_{3} / \mathrm{TiO}_{2}$ stack is applied as an electron-selective contact on n-type c-Si solar cells. This ETL approach has not been reported in the literature on finished photovoltaic devices. In this paper, combining this new ETL concept together with a previously explored HTL stack (Ni-coated $\mathrm{V}_{2} \mathrm{O}_{x}$ ), ${ }^{19}$ we report on highly efficient low-temperature and dopant-free n-type IBC c-Si solar cells with conversion efficiencies up to $19.1 \%$ on $9 \mathrm{~cm}^{2}$ devices. It is important to stress that both selective contacts (ETL and HTL) are fabricated at temperatures lower than $100{ }^{\circ} \mathrm{C}$ reducing the overall thermal budget of the fabrication process. Additionally the low resistivity values achieved using the ETL proposed herein allow us to circumvent the use of Indium Tin Oxide (ITO), further simplifying the fabrication process and eliminating the use of scarce materials.

\section{Results and discussion}

Surface contact passivation has been evaluated by extracting both the effective surface recombination velocity and the implicit open-circuit voltage $\left(i V_{\mathrm{oc}}\right)$ from effective lifetime $\left(\tau_{\text {eff }}\right)$ measurements using the quasi-steady-state photoconductance decay technique (QSS-PC). ${ }^{26}$ Passivation test samples were fabricated on n-type float zone $\langle 100\rangle \mathrm{c}$-Si substrates. One side was almost ideally passivated by means of a thick $\mathrm{Al}_{2} \mathrm{O}_{3}$ film (50 $\mathrm{nm}),{ }^{19,27}$ allowing us to neglect the corresponding recombination in the effective lifetime measurements. The other side was covered with the $\mathrm{Al}_{2} \mathrm{O}_{3} / \mathrm{TiO}_{2}$ stack under investigation with different film thicknesses. Fig. 1 shows the $i V_{\text {oc }}$ values as a function of the number of $\mathrm{Al}_{2} \mathrm{O}_{3}$ and $\mathrm{TiO}_{2} \mathrm{ALD}$ cycles, i.e. film thickness. Firstly, setting the number of $\mathrm{Al}_{2} \mathrm{O}_{3}$ ALD cycles to 3 , 20 cycles of $\mathrm{TiO}_{2}$ seem to be the best choice from a passivation point of view, resulting in $\tau_{\text {eff }}$ and $i V_{\text {oc }}$ values of $660 \mu \mathrm{s}$ (see ESI Fig. S1 $\dagger$ ) and $683 \mathrm{mV}$, respectively. Both increasing and decreasing the number of $\mathrm{TiO}_{2}$ cycles lead to a poorer surface passivation quality. This trend has already been reported by $\mathrm{X}$. Yang et $a .^{28}$ Secondly, when setting the number of $\mathrm{TiO}_{2} \mathrm{ALD}$ cycles to $20, i V_{\mathrm{oc}}$ increases monotonically with the number of $\mathrm{Al}_{2} \mathrm{O}_{3}$ cycles achieving an $i V_{\mathrm{oc}}$ value of $685 \mathrm{mV}\left(S_{\text {eff }}\right.$ of $\left.33 \mathrm{~cm} \mathrm{~s}^{-1}\right)$ for 12 ALD cycles. Information about the $S_{\text {eff }}$ extraction can be found in the ESI. $\uparrow$ Thus, we conclude that an $\mathrm{Al}_{2} \mathrm{O}_{3}$ interlayer between $\mathrm{TiO}_{2}$ and c-Si improves the passivation, increasing the $i V_{\text {oc }}$ from 667 to $687 \mathrm{mV}$ as is also shown from an effective lifetime point of view in the ESI (Fig. S1 $\dagger$ ). Notice that no annealing is required to activate the passivation of the $\mathrm{Al}_{2} \mathrm{O}_{3}$ / $\mathrm{TiO}_{2}$ stacks. It is also important to stress that surface 


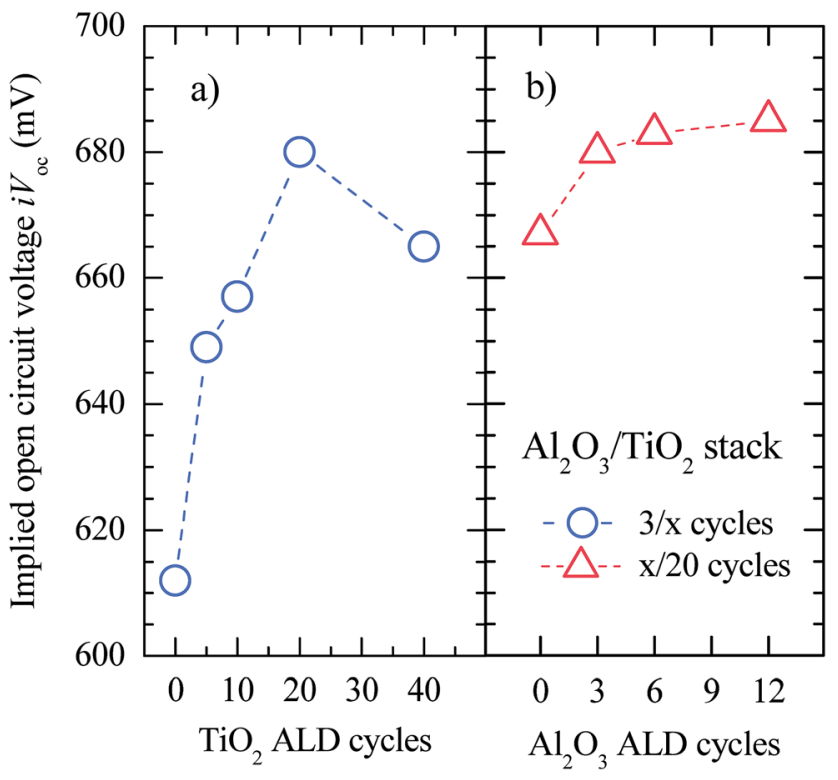

Fig. 1 Implied open circuit voltage $\left(i V_{\text {oc }}\right)$ values extracted from the measured effective lifetime $\left(\tau_{\text {eff }}\right)$ at different $\mathrm{TiO}_{2}$ and $\mathrm{Al}_{2} \mathrm{O}_{3}$ ALD cycles. (a) Study varying the number of $\mathrm{TiO}_{2}$ ALD cycles and fixing the number of ALD cycles for the $\mathrm{Al}_{2} \mathrm{O}_{3}$ film at 3. (b) Study varying the number of $\mathrm{Al}_{2} \mathrm{O}_{3}$ ALD cycles and fixing the number of ALD cycles for the $\mathrm{TiO}_{2}$ film at 20. Dashed lines are given as a guide to the eye.

passivation is stable up to a temperature of $250{ }^{\circ} \mathrm{C}$ as is shown in the ESI (Fig. S2 $\dagger$ ), which is enough to perform the following technological steps and a hypothetical encapsulationlamination at $150{ }^{\circ} \mathrm{C}$.

The excellent surface passivation provided by the $\mathrm{ALD} \mathrm{Al}_{2} \mathrm{O}_{3}$ films is due to both chemical and physical passivation mechanisms. ${ }^{29}$ In other words, the silicon surface passivation when covered with $\mathrm{Al}_{2} \mathrm{O}_{3}$ originates on one hand from the low surface state density and simultaneously from the electric field effect due to the inherent charge in these films. In annealed $\mathrm{Al}_{2} \mathrm{O}_{3}$ films this charge is negative. However, it has been reported that relatively thick dielectric $\mathrm{Al}_{2} \mathrm{O}_{3} / \mathrm{TiO}_{2}$ stacks $(\sim 20 \mathrm{~nm})$ exhibit a net positive charge even after an annealing stage at $400{ }^{\circ} \mathrm{C} .{ }^{30}$ Nevertheless, the details of the origin of surface passivation in ultra-thin conductive $\mathrm{Al}_{2} \mathrm{O}_{3} / \mathrm{TiO}_{2}$ structures and the passivation behaviour with annealing temperature are still unclear and further research in this field is required.

Although $\mathrm{Al}_{2} \mathrm{O}_{3} / \mathrm{TiO}_{2}$ stacks provide excellent surface passivation on n-type silicon substrates, good electron conduction properties are mandatory for electron-selective contacts. To check the contact quality and the influence of the metal capping on its electrical behaviour, test samples were fabricated on n-type c-Si substrates. The same $\mathrm{Al}_{2} \mathrm{O}_{3} / \mathrm{TiO}_{2}$ stacks were deposited on both sides of bare c-Si substrates. Then, one side was totally covered with the capping metal $(\mathrm{Mg}, \mathrm{Al}$ or $\mathrm{Ni})$ with a thickness of around $15 \mathrm{~nm}$ and finished with an extra $150 \mathrm{~nm}$ thick Al layer, whereas the other side was selectively metalized with the same electrode materials using a shadow mask in order to define dot features with different diameters (see the sketch in the inset of Fig. 2). The $150 \mathrm{~nm}$ thick Al layers a)

b)

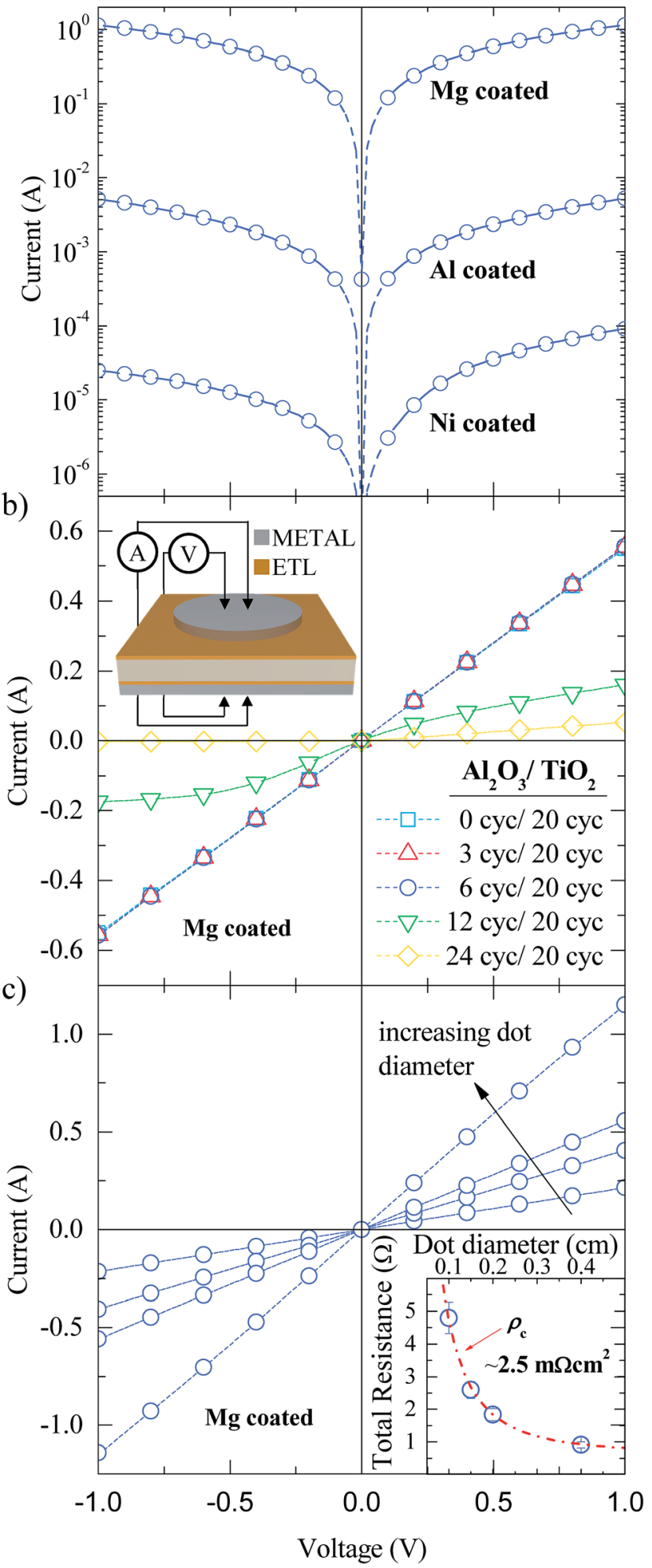

Fig. 2 (a) Impact of metal capping material on the measured dark current-voltage ( $-V$ characteristics using $\mathrm{Al}_{2} \mathrm{O}_{3} / \mathrm{TiO}_{2}$ stacks (6/20 ALD cycles) for $4 \mathrm{~mm}$ diameter spots. (b) Influence of the number of $\mathrm{Al}_{2} \mathrm{O}_{3}$ ALD cycles on I-V curves using Mg-coated samples (with 20 ALD cycles of $\mathrm{TiO}_{2}$ ). The test structure is depicted in the inset. In this case, $2 \mathrm{~mm}$ diameter spots were used. (c) $\mathrm{I}-\mathrm{V}$ measurements of $\mathrm{Mg}$-coated $\mathrm{Al}_{2} \mathrm{O}_{3} /$ $\mathrm{TiO}_{2}$ stacks (6/20 ALD cycles) as a function of contact dot diameter. Contact resistance $\left(\rho_{\mathrm{c}}\right)$ extraction by fitting the total resistance $\left(R_{\mathrm{T}}\right)$ curve through 3D simulations (dashed line) is shown in the inset. 
Table 1 Summary of ETL strategies applied on n-type c-Si substrates and their relevant contact quality parameters. In the lower part of the table are the $\mathrm{TiO}_{2}$-based approaches

\begin{tabular}{|c|c|c|c|c|c|c|}
\hline ETL approach & $i V_{\mathrm{oc}}(\mathrm{mV})$ & $J_{\mathrm{oc}}\left(\mathrm{fA} \mathrm{cm}^{-2}\right)$ & $S_{\text {eff }}\left(\mathrm{cm} \mathrm{s}^{-1}\right)$ & $\rho_{\mathrm{c}}\left(\mathrm{m} \Omega \mathrm{cm}^{2}\right)$ & $S_{10}$ & Ref. \\
\hline $\mathrm{a}-\mathrm{Si}: \mathrm{H}(\mathrm{i})(6 \mathrm{~nm}) / \mathrm{LiF}_{x}(1 \mathrm{~nm}) / \mathrm{Al}$ & $732^{a}$ & $3^{a}$ & - & 7 & 15.1 & 6 \\
\hline $\mathrm{MgO}_{x}(1 \mathrm{~nm}) / \mathrm{Al}$ & - & - & - & 17.5 & - & 15 \\
\hline $\mathrm{MgF}_{2}(1 \mathrm{~nm}) / \mathrm{Al}$ & 534 & 1500 & - & 35 & 8.7 & 9 \\
\hline $\mathrm{a}-\mathrm{Si}: \mathrm{H}(\mathrm{i})(6.5 \mathrm{~nm}) / \mathrm{MgF}_{2}(1 \mathrm{~nm}) / \mathrm{Al}$ & 710 & 10 & - & 76 & 13.5 & 9 \\
\hline $\mathrm{TiO}_{2}(2.5 \mathrm{~nm}) / \mathrm{Al}$ & - & $132^{b}$ & 56 & 20 & 10.0 & 20 \\
\hline $\mathrm{Al}_{2} \mathrm{O}_{3}(0.5 \mathrm{~nm}) / \mathrm{TiO}_{2}(1.5 \mathrm{~nm}) / \mathrm{Mg} / \mathrm{Al}$ & $683^{c}$ & $140^{b}$ & 40 & 2.5 & 13.9 & This work \\
\hline
\end{tabular}

${ }^{a}$ Reported values related to contact passivation have been measured before $\mathrm{LiF}_{x}$ deposition. ${ }^{b}$ Extrapolated using the relationship $J_{0 \mathrm{c}}=S_{\text {eff }} \times q n_{\mathrm{i}}{ }^{2} /$ $N_{\mathrm{D}}$ from current $S_{\text {eff }}$ values, where $N_{\mathrm{D}}, q$ and $n_{\mathrm{i}}$ are the substrate doping, elementary charge and intrinsic concentration $\left(n_{\mathrm{i}}=8.56 \times 10^{9} \mathrm{~cm}^{-3}\right.$ at $T=$ $25{ }^{\circ} \mathrm{C}$ ), respectively; see the ESI. ${ }^{c}$ Measured in asymmetric test samples (one side ideally passivated).

are deposited without breaking the vacuum and serve to facilitate the measurements.

Semi-log $I-V$ curves for a reference $\mathrm{Al}_{2} \mathrm{O}_{3} / \mathrm{TiO}_{2}$ stack $(6 / 20$ ALD cycles) with the different metal layers are shown in Fig. 2a. For a direct comparison, the $I-V$ measurements were performed on dot features with the same pad diameter $(4 \mathrm{~mm})$ for all capping metals. The best behaviour corresponds to the sample in contact with $\mathrm{Mg} / \mathrm{Al}$ achieving a low resistance ohmic curve with currents two orders of magnitude higher than that of the sample in contact with only Al. In contrast, the worst result is obtained for the sample in contact with $\mathrm{Ni} / \mathrm{Al}$, which results in a non-ohmic curve (see the asymmetric current level). Therefore, metal capping plays an important role in the functioning of the ETL structure. Note that depending on the metal material, the work function $(\varphi)$ changes from a low to a high value $\left(\varphi_{\mathrm{Mg}} \sim 3.6 \mathrm{eV}, \varphi_{\mathrm{Al}} \sim 4.3 \mathrm{eV}\right.$ and $\left.\varphi_{\mathrm{Ni}} \sim 5.1 \mathrm{eV}\right)$. The electrical contact quality improves with diminishing metal work function as expected in metal-semiconductor contacts on c-Si(n) substrates, i.e. the lower the work function value, the lower the contact barrier height, and the higher the majority carrier conduction through the silicon/contact interface. A similar behaviour has also been reported with a-Si:H passivated contacts using either $\mathrm{Mg} / \mathrm{Al}$ or $\mathrm{Al}$ metal capping. ${ }^{31}$

In Fig. $2 \mathrm{~b}$ the impact of the $\mathrm{Al}_{2} \mathrm{O}_{3}$ interlayer thickness ranging from 0 to $24 \mathrm{ALD}$ cycles on the electrical contact quality is shown. In all cases, the thickness of the $\mathrm{TiO}_{2}$ layer was fixed at $20 \mathrm{ALD}$ cycles and $\mathrm{Mg} / \mathrm{Al}$ was used as a capping electrode. As we can see in this figure, for voltages from -1 to $1 \mathrm{~V}$ the characteristics are clearly ohmic for 0,3 , and even 6 ALD cycles. Nevertheless, this electrical behaviour changes to a poor ohmic contact for 12 ALD cycles, and exhibits a pseudo-rectifying $I-V$ curve for the the case of $24 \mathrm{ALD}$ cycles. This fact is in agreement with the dielectric nature of $\mathrm{ALD} \mathrm{Al}_{2} \mathrm{O}_{3}$ films, which must finally block the electron-extraction, i.e. the tunnel conduction mechanism vanishes. Consequently, $\mathrm{Al}_{2} \mathrm{O}_{3}$ films prepared with 6 cycles $(\sim 0.5 \mathrm{~nm})$ yield the optimum trade-off between good passivation (thick films) and good electrical contact performance (thin films).

Fig. 2c shows the $I-V$ curves for different dot-like contact diameters with the best stack configuration, $\mathrm{Al}_{2} \mathrm{O}_{3}$ ( 6 cycles $) /$
$\mathrm{TiO}_{2}(20$ cycles $) / \mathrm{Mg}$. The specific contact resistance $\left(\rho_{\mathrm{c}}\right)$ of the stack can be extracted by fitting the measured total resistance $\left(R_{\mathrm{T}}\right)$ for the different dot diameters using 3D simulations (Silvaco ATLAS TCAD).$^{32}$ The results can be seen in the inset of Fig. 2c. Excellent $\rho_{\mathrm{c}}$ values of $2.5 \pm 0.5 \mathrm{~m} \Omega \mathrm{cm}^{2}$ are obtained for our electron-selective contacts. Cumulative 5 min annealings have been performed showing stable results both for the specific contact resistance and for the $i V_{\text {oc }}$ up to $200^{\circ} \mathrm{C}$ (see ESI Fig. S2 $\dagger$ ). This result improves $\rho_{\mathrm{c}}$ by more than one order of magnitude compared to $\mathrm{SiO}_{2} / \mathrm{TiO}_{2}$ stacks on n-type substrates. ${ }^{20}$ It is important to point out that small $\rho_{\mathrm{c}}$ values are crucial for manufacturing non-full contact high efficiency solar cells, in which the ETL coverage area fraction $\left(f_{\text {ETL }}\right)$, defined as the ratio between ETL and total cell area, is typically in the 1-10\% range. Considering that the specific series resistance $\left(r_{\mathrm{s}}\right)$ is limited only by the ETL contact quality, the total series resistance could be roughly calculated as $r_{\mathrm{s}} \cong \rho_{\mathrm{c}} \times 100 / f_{\text {ETL }}(\%)$, yielding for the worst case $\left(f_{\text {ETL }}=1 \%\right)$ values below $\sim 0.3 \Omega \mathrm{cm}^{2}$ in final devices.

Finally, a single figure of merit quantifying contact quality is the so-called contact selectivity $\left(S_{10}\right)$ defined as $S_{10}=\log \left(V_{\text {th }} /\left(\rho_{\mathrm{c}}\right.\right.$ $\left.\left.\times J_{0 \mathrm{c}}\right)\right),{ }^{33}$ where $V_{\text {th }}$ is the thermal voltage $\left(25.69 \mathrm{mV}\right.$ at $\left.25^{\circ} \mathrm{C}\right)$ and $J_{0 \mathrm{c}}$ is the contact recombination current density. This parameter is an alternative way to characterize surface recombination and can be calculated from the more common $S_{\text {eff }}$ concept (see the ESI $\dagger$ where a detailed explanation of this calculation can be found). Good contacts are characterized by simultaneously low $\rho_{\mathrm{c}}$ and $J_{0 \mathrm{c}}$ values. Thus, the higher the $S_{10}$ value, the better the contact behaviour. Table 1 compares the main figures of merit reported in the literature for different ETLs. As can be observed, although the use of a thin a-Si:H(i) or alternatively a thermal $\mathrm{SiO}_{2}$ film as a passivating interlayer provides excellent surface passivation, these approaches usually exhibit poor conductivity, i.e. high contact resistance values. The ETL stack reported herein achieves a remarkable $S_{10}$ value of 13.9, which is the best result for electron collector layers without using any PECVD or thermally grown passivation interlayer.

In order to investigate the surface chemical composition of the reference $\mathrm{Al}_{2} \mathrm{O}_{3} / \mathrm{TiO}_{2}$ stack (6/20 ALD cycles), both uncoated and $\mathrm{Mg}$-coated samples were analysed by the X-ray photoelectron spectroscopy (XPS) technique. In Fig. 3 the XPS analysis 
a)

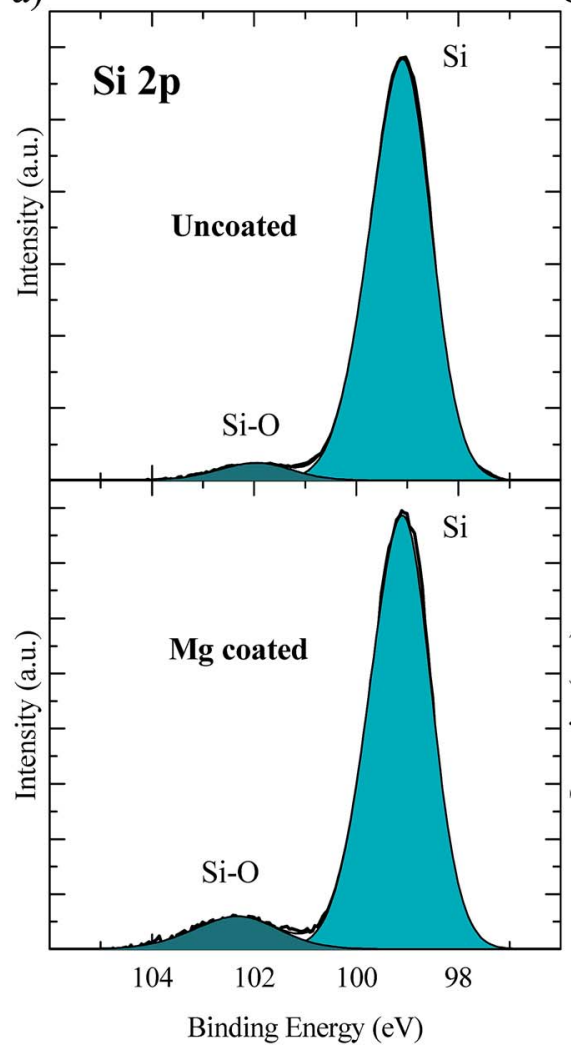

b)

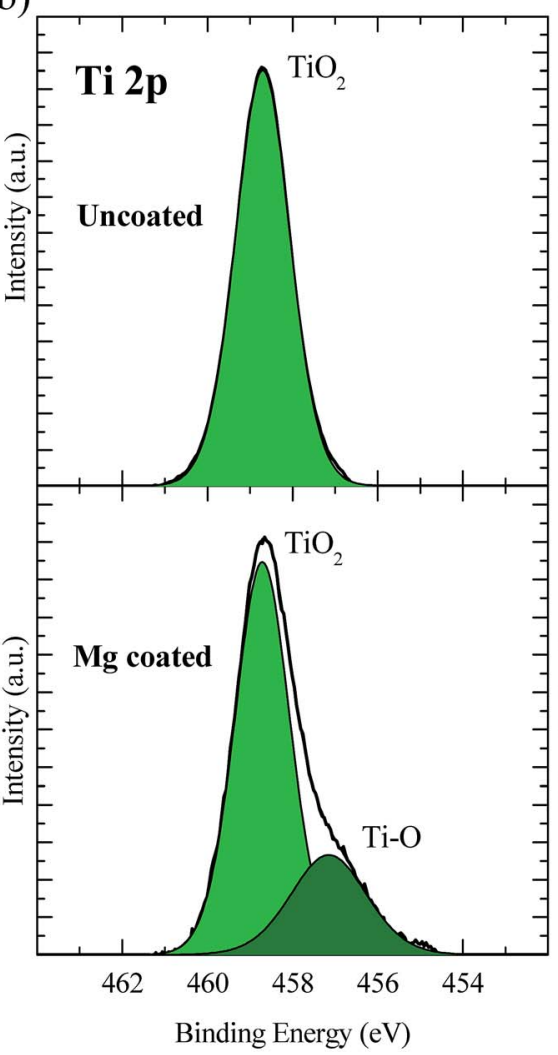

c)

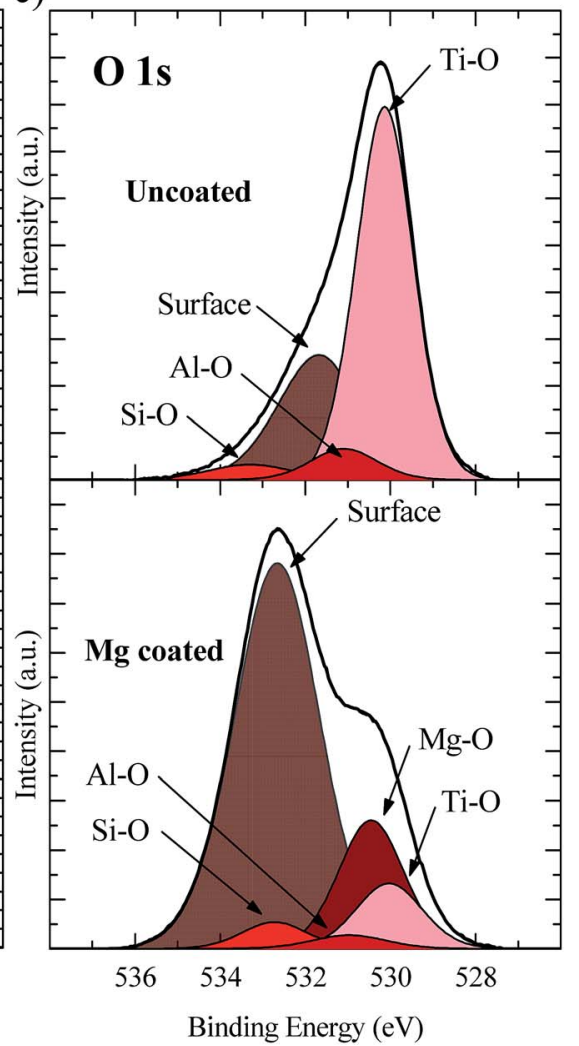

Fig. 3 High-resolution XPS spectra of both uncoated and Mg-coated $\mathrm{Al}_{2} \mathrm{O}_{3} / \mathrm{TiO}_{2}$ stacks (6/20 ALD cycles) on n-type c-Si substrates. (a) Si $2 \mathrm{p}$, (b) $\mathrm{Ti} 2 \mathrm{p}$ and (c) $\mathrm{O}$ 1s core levels spectra showing the multi-peak deconvolution of the fitted curves for different cation oxidation states.

results of $\mathrm{Si} 2 \mathrm{p}$, Ti 2p, and $\mathrm{O}$ 1s core levels for both samples are compared. In both cases, two peaks appear in the Si $2 \mathrm{p}$ spectrum (Fig. 3a). These peaks, which correspond to bulk Si and silicon oxide (Si-O) states, can be deconvoluted and fitted using
Gaussian-Lorentzian curves centred at $\sim 99.0$ and $\sim 102.0 \mathrm{eV}$ binding energies, respectively. Since a HF dip was performed just before the ALD stack growth, oxidation of the Si surface might occur during the first water pulse in the $\mathrm{Al}_{2} \mathrm{O}_{3}$ deposition a)

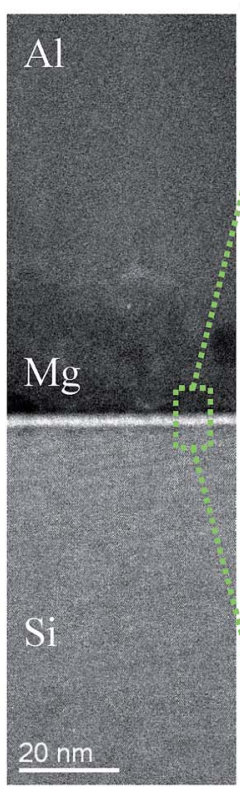

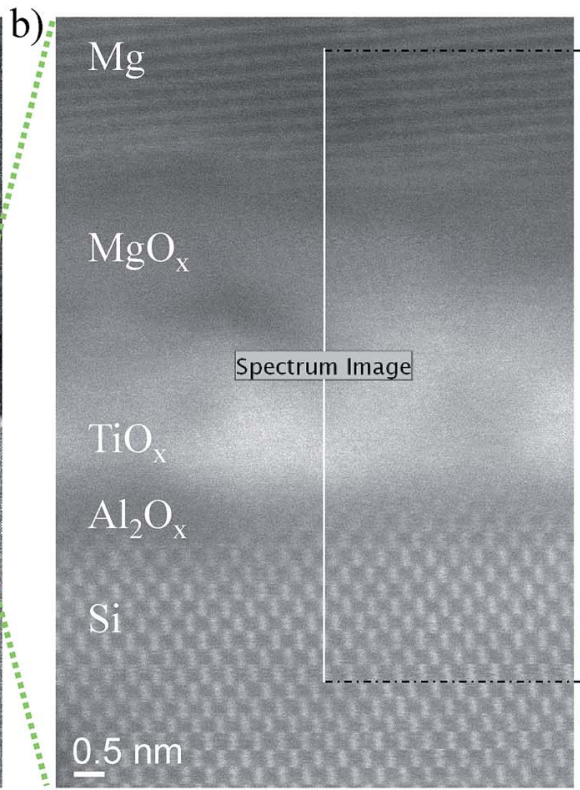

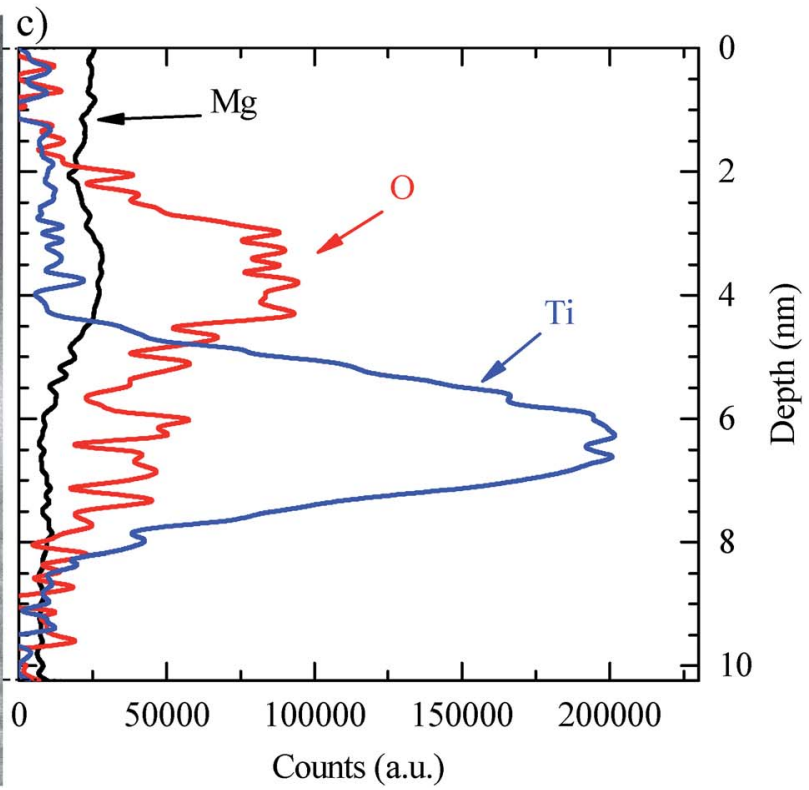

Fig. 4 (a) High-resolution STEM image of contact resistance test samples of a Mg-coated $\mathrm{Al}_{2} \mathrm{O}_{3} / \mathrm{TiO}_{2}$ stack (6/20 ALD cycles). (b) A close view of the $\mathrm{Al}_{2} \mathrm{O}_{3} / \mathrm{TiO}_{2} / \mathrm{Mg}$ stack. (c) EELS line scan confirming an $\mathrm{MgO}_{x}$ interlayer grown in between $\mathrm{TiO}_{2}$ and $\mathrm{Mg}$ films. 
stage, where the Si dangling bonds react with oxygen. Additionally, ESI Fig. S3b † shows the Al 2p core level spectrum where the $\mathrm{Al} 2 \mathrm{p}_{3 / 2}$ peak centred at a binding energy of $\sim 74.2 \mathrm{eV}$ confirms the existence of the alumina compound.

The Ti $2 p_{3 / 2}$ core level spectrum is shown in Fig. 3 b. For the uncoated sample, a single peak centred at a binding energy of $\sim 458.7 \mathrm{eV}$ is enough to fit the curve. However, an extra peak centred at $\sim 457.1 \mathrm{eV}$ appears for the Mg-coated sample. The peak at higher binding energy corresponds to a fully oxidized $\mathrm{TiO}_{2}$, while the lower binding energy peak is assigned to a titanium rich $\mathrm{TiO}_{x}$ layer. ${ }^{24}$ From the relative area of the Ti-O peak with respect to the $\mathrm{Ti} 2 \mathrm{p}$ spectrum, an approximate $\mathrm{TiO}_{x}$ content of $26 \%$ was calculated, indicating that only a fraction of the $\mathrm{TiO}_{2}$ layer is under-stoichiometric. The TMO work function changes strongly with the film stoichiometry, ${ }^{34}$ i.e. oxygen-deficient layers exhibit lower work function values and a semi-metallic behaviour. In our devices, these effects might enhance the electron selectivity because of a proper band alignment and an improvement of layer conductivity. This oxygen deficiency could be attributed to a reaction of the thermally evaporated $\mathrm{Mg}$ with the $\mathrm{TiO}_{2}$, forming a magnesium oxide layer $\left(\mathrm{MgO}_{x}\right)$. This hypothesis is corroborated by the $\mathrm{Mg} 2 \mathrm{p}$ spectrum, which exhibits a peak centred at a binding energy of $\sim 50.8 \mathrm{eV}$ corresponding to an $\mathrm{Mg}-\mathrm{O}$ compound (ESI Fig. S3a $\dagger$ ).

Finally, an analysis of the $\mathrm{O} 1 \mathrm{~s}$ core level spectrum (Fig. 3c) corroborates the presence of the many chemical species mentioned above. First, $\mathrm{Al}-\mathrm{O}$ and $\mathrm{Ti}-\mathrm{O}$ species (with a characteristic binding energy of $\sim 531.5 \mathrm{eV}$ and $\sim 530.0 \mathrm{eV}$ respectively) are identified in both samples, which correspond to the $\mathrm{TiO}_{2}$ and $\mathrm{Al}_{2} \mathrm{O}_{3}$ layers. However, the $\mathrm{Mg}$-coated sample shows a smaller Ti-O intensity, attenuated by the $\mathrm{Mg}$ on top, as well as a $\mathrm{Mg}-\mathrm{O}$ peak at $530.4 \mathrm{eV}$, confirming the presence of $\mathrm{MgO}_{x}$ in the $\mathrm{TiO}_{2} / \mathrm{Mg}$ interface. An interesting feature is the detection of carbon contaminants adsorbed to the surface after airexposure, whose contribution is particularly high for the $\mathrm{Mg}$ coated sample $(\sim 532.8 \mathrm{eV})$ and can be attributed to metal carbonate species, i.e. $\mathrm{MgCO}_{3} \cdot{ }^{35}$ Also, the $\mathrm{Si}-\mathrm{O}$ component $(\sim 533.0 \mathrm{eV})$ is discernible for both samples.

In order to get a better insight into the influence of $\mathrm{Mg}$ on both the chemistry of $\mathrm{Al}_{2} \mathrm{O}_{3} / \mathrm{TiO}_{2}$ stacks and the electrical contact performance, we analysed their chemical composition using both energy dispersive X-ray spectroscopy (EDX) and electron energy loss spectroscopy (EELS) analysis. In Fig. 4a the high-angle annular dark field (HAADF) scanning transmission electron microscope (STEM) image reveals details of the contact structure. Firstly, a $\sim 15 \mathrm{~nm}$ thick $\mathrm{Mg}$ layer is observed as well as $\mathrm{a} \sim 2 \mathrm{~nm}$ thick $\mathrm{Al}_{2} \mathrm{O}_{3} / \mathrm{TiO}_{2}$ stack. With the closer view shown in Fig. $4 \mathrm{~b}$, an $\mathrm{Al}_{2} \mathrm{O}_{3}$ interlayer $(\sim 0.5 \mathrm{~nm})$ was observed in the $\mathrm{TiO}_{2} /$ c-Si interface capped with a $\sim 1.5 \mathrm{~nm}$ thick $\mathrm{TiO}_{2}$ layer. Due to the strong oxygen affinity of $\mathrm{Mg}$ metal, magnesium atoms easily attract oxygen atoms from the $\mathrm{TiO}_{2}$ interlayer forming an $\mathrm{MgO}_{x}$ layer with a thickness of $\sim 2 \mathrm{~nm}$. The existence of this extra layer is in agreement with the previous XPS measurements and confirmed by the EELS chemical composition cross scanning (see Fig. 4c). Interestingly, a similar behaviour was also observed when aluminium was evaporated directly onto $\mathrm{TiO}_{2}$ layers forming in this case an $\mathrm{AlO}_{x}$ layer (see ESI Fig. S4 $\dagger$ ), in agreement with other reported studies. ${ }^{20}$ However, if $\mathrm{Mg}$ is used as a capping metal electrode, the spontaneous growth of a $\mathrm{MgO}_{x}$ film may enhance the electron-selectivity of our contacts due to the already reported ETL nature of magnesium oxide. ${ }^{15}$

To demonstrate the viability of $\mathrm{Al}_{2} \mathrm{O}_{3} / \mathrm{TiO}_{2} / \mathrm{Mg}$ stacks as electron-selective contacts for c-Si solar cells, we fabricated a proof-of-concept $3 \times 3 \mathrm{~cm}^{2}$ IBC structure on n-type c-Si substrates. The inset of Fig. 5a depicts the cell structure. The front-textured surface was covered with a $50 \mathrm{~nm}$ thick $\mathrm{Al}_{2} \mathrm{O}_{3}$ layer and further coated up to $75 \mathrm{~nm}$ with a close to stoichiometric silicon carbide layer $\left(\mathrm{a}-\mathrm{SiC}_{x}\right)$ providing excellent passivation as

a)
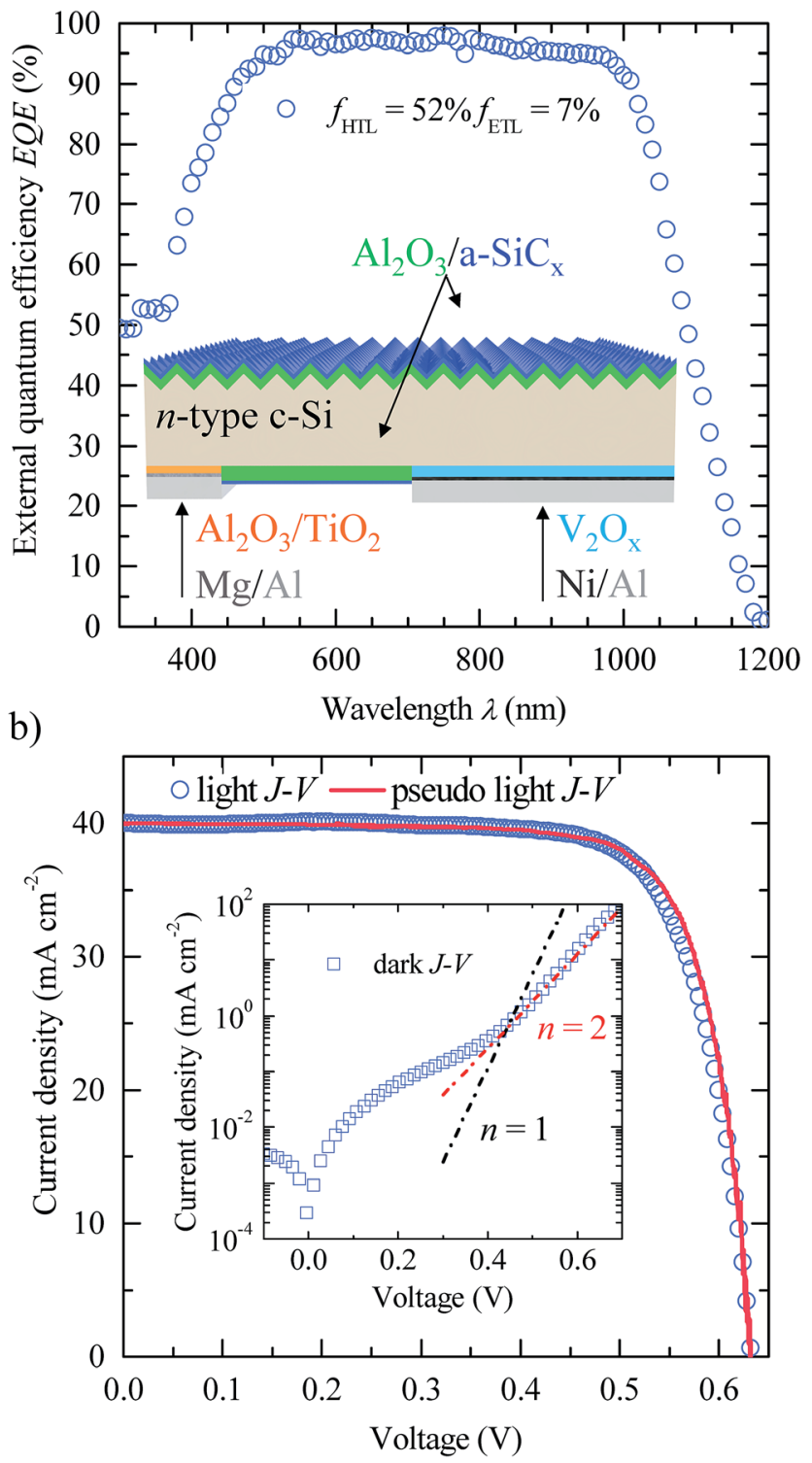

Fig. 5 (a) EQE curve of the best IBC solar cell $\left(f_{\mathrm{HTL}} / f_{\mathrm{ETL}}=52 \% / 7 \%\right.$ coverage values). A sketch of the device concept is shown in the inset. (b) Light $J-V$ and pseudo light $J-V$ curves for this IBC solar cell. The pseudo $J-V$ characteristic, free of series resistance effects, is determined from Suns $-V_{\text {oc }}$ measurements. The dark $J-V$ characteristic is depicted in the inset showing ideal exponential trends (lines) with ideality factors ( $n$ ) of 1 and 2 . 
Table 2 Summary of the IBC solar cell parameters measured under standard test conditions $\left(1 \mathrm{~kW} \mathrm{~m}{ }^{-2}, \mathrm{AM} 1.5 \mathrm{G}\right.$ spectrum, $\left.25^{\circ} \mathrm{C}\right)$ for the four device topologies $\left(9 \mathrm{~cm}^{2}\right.$ device area)

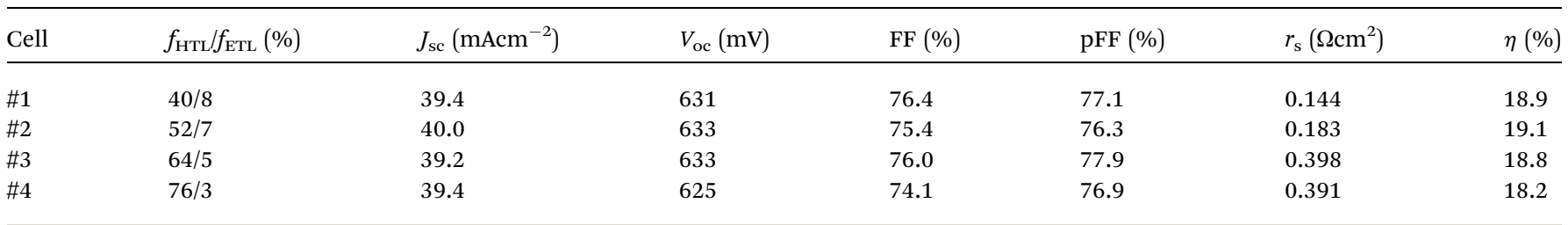

well as antireflection properties. ${ }^{36}$ It is important to point out that the gap between the interdigitated back-contacts is also passivated with the same stack. Therefore all non-contact surfaces are covered with a passivating and light confining $\mathrm{Al}_{2} \mathrm{O}_{3} / \mathrm{SiC}_{x}$ stack which redirects light towards the bulk of the absorber and photogenerated carriers towards the corresponding contact.

External quantum efficiency (EQE) measurements for the best device are shown in Fig. 5a. EQE values close to $97 \%$ in the visible wavelength range confirm an excellent front and rear surface passivation pointing out that electron-selectivity in our ETL regions is good enough to obtain high photovoltaic efficiencies. Short circuit current densities $\left(J_{\mathrm{sc}}\right)$ of about $40 \mathrm{~mA}$ $\mathrm{cm}^{-2}$ and efficiencies $(\eta)$ in the $18-19 \%$ range independently of the ETL coverage $\left(f_{\mathrm{ETL}}\right)$ have been measured, suggesting that surface passivation in the ETL regions is good enough to avoid excessive electrical shadowing. ${ }^{37}$ A similar high-efficiency structure has recently been reported combining a $\mathrm{LiF}_{x}$-based ETL and $\mathrm{V}_{2} \mathrm{O}_{x}-$ metal $-\mathrm{V}_{2} \mathrm{O}_{x}$ as the HTL in an IBC structure. ${ }^{12}$ However, in that device a high temperature phosphorus diffusion stage is needed to form a front surface field (FSF).

Details related to the photovoltaic parameters of the fabricated solar cells are listed in Table 2 . Open circuit voltages $\left(V_{\mathrm{oc}}\right)$ of up to $633 \mathrm{mV}$ and fill factors (FF) of around 75\% are achieved in our devices. Another interesting analysis is shown in Fig. 5b, where the illuminated current density-voltage $(J-V)$ curve for the best IBC solar cell is compared with the corresponding pseudo-light $J-V$ curve from Suns $-V_{\text {oc }}$ measurements. ${ }^{38}$ These measurements allow the determination of a pseudo $J-V$ curve that excludes the series-resistance contribution. The matching between these two curves suggests that series resistance is not the limiting factor in the efficiency, as is corroborated by similar values of fill factor and pseudo-FF (pFF) parameters. The specific series resistance calculated using the relationship $r_{\mathrm{s}} \cong$ $(1-\mathrm{FF} / \mathrm{pFF}) \times V_{\mathrm{oc}} / J_{\mathrm{sc}}{ }^{39}$ yields values below $0.4 \Omega \mathrm{cm}^{2}$ in all cases, confirming the high contact quality of our ETL stacks.

The relatively low FF can be attributed to a diode ideality factor $(n)$ close to two as can be seen in the dark $J-V$ curve shown in the inset of Fig. 5b. This high $n$ value might be attributed to poor coverage at the edges of the strip-like regions of the $\mathrm{V}_{2} \mathrm{O}_{x^{-}}$ based HTL as is explained in detail in the ESI. $\uparrow$ This drawback could be overcome in the future using the ALD technique to deposit both ETL and HTL selective contacts.

\section{Conclusions}

In this work, we apply atomic layer deposition of aluminium and titanium oxide $\left(\mathrm{Al}_{2} \mathrm{O}_{3} / \mathrm{TiO}_{2}\right)$ stacks to form electron- selective contacts for interdigitated back-contacted n-type c-Si solar cells.

The use of a very thin $\mathrm{ALD} \mathrm{Al}_{2} \mathrm{O}_{3}$ passivation interlayer $(\sim 0.5$ $\mathrm{nm})$ between silicon and the thin $\mathrm{TiO}_{2}$ film $(\sim 1.5 \mathrm{~nm})$ improves contact surface passivation, yielding surface recombination velocities below $33 \mathrm{~cm} \mathrm{~s}^{-1}$ and implicit open circuit voltages of about $680 \mathrm{mV}$ in our test devices. Additionally, the metal capping layer plays an important role in contact conductivity, $\mathrm{Mg}$ being the best choice of material, with specific contact resistance values as low as $2.5 \mathrm{~m} \Omega \mathrm{cm}^{2}$ being reached. Chemical composition analysis (XPS and EELS) confirms spontaneous growth of a $\mathrm{MgO}_{x}$ layer, leaving an oxygen-deficient $\mathrm{TiO}_{x}$ layer in our Mg-coated samples.

Finally, the optimum electron-selective contact configuration consisting of an $\mathrm{Al}_{2} \mathrm{O}_{3}$ (6 ALD cycles)/ $\mathrm{TiO}_{2}$ (20 ALD cycles)/ $\mathrm{Mg}$ stack was applied to an interdigitated back-contacted solar cell structure using a $\mathrm{V}_{2} \mathrm{O}_{x} / \mathrm{Ni}$ stack as a hole transport layer. In this way, fully TMO-based $\left(9 \mathrm{~cm}^{2}\right.$ area) solar cells reaching efficiencies up to $19.1 \%$ through a dopant-free and lowtemperature fabrication process have been fabricated. These results outline the potential of TMOs to improve the trade-off between technological complexity and efficiency in Si solar cells.

\section{Experimental}

All the structures were fabricated using high quality $\langle 100\rangle$ planar float zone (FZ) n-type c-Si wafers with a resistivity of $2 \pm 1$ $\Omega \mathrm{cm}$ and a thickness of $280 \pm 10 \mu \mathrm{m}$. The general trends of the IBC cell fabrication process have been described in a previous study. ${ }^{19}$ In this work the $\mathrm{Al}_{2} \mathrm{O}_{3} / \mathrm{TiO}_{2} / \mathrm{Mg}$ stack replaces laser doped contacts to create ETL regions. Therefore, fully lowtemperature and dopant-free IBC solar cells based on TMOs have been fabricated. Photovoltaic parameters and illuminated $J-V$ curves were measured under standard test conditions $(1 \mathrm{~kW}$ $\mathrm{m}^{-2}$, AM1.5G solar spectrum, $25{ }^{\circ} \mathrm{C}$ ) using an ORIEL 94021A (Newport) solar simulator. Light irradiance was properly calibrated by means of a pyranometer. The EQE curves were measured using a commercial instrument (QEX10, PV measurements) with a white light bias of 0.2 Suns and a beam spot of $2 \times 2 \mathrm{~cm}^{2}$ centred within the active device area.

The passivation test samples were subjected to a cleaning sequence of RCA1/2 (ref. 40) and a diluted HF (1\%) dip prior to deposition at $200{ }^{\circ} \mathrm{C}$ on both sides of a $50 \mathrm{~nm}$ thick $\mathrm{Al}_{2} \mathrm{O}_{3}$ layer by ALD (Savannah S200, Cambridge Nanotech). Trimethylaluminium (TMA) and water were used as the aluminium precursor and oxidant species, respectively. A subsequent 10 min annealing was performed in forming gas $\left(\mathrm{H}_{2} / \mathrm{N}_{2}\right)$ at 
$400{ }^{\circ} \mathrm{C}$ in order to activate the surface passivation provided by the $\mathrm{Al}_{2} \mathrm{O}_{3}$ films. ${ }^{27,36}$ Then, a $35 \mathrm{~nm}$ thick a-SiC $x_{x}$ layer was deposited on one side by a plasma-enhanced chemical vapour deposition (PECVD) process (13.56 MHz, from Elettrorava S.p.A) at a temperature of $300{ }^{\circ} \mathrm{C}$ from silane $\left(\mathrm{SiH}_{4}\right)$ and methane $\left(\mathrm{CH}_{4}\right)$ precursor gases. This a-SiC $x$ layer protects the films underneath against subsequent cleaning and HF dips. Finally, after a diluted RCA1-based cleaning ${ }^{41}$ and a HF (1\%) dip to etch the thick alumina film (obtaining a hydrophobic surface), the $\mathrm{Al}_{2} \mathrm{O}_{3} / \mathrm{TiO}_{2}$ stack was deposited by ALD at $100{ }^{\circ} \mathrm{C}$ using the same ALD equipment. The stack was deposited without breaking the vacuum with an estimated growth rate of $1 \AA$ per cycle and 0.63 $\AA$ per cycle for alumina and titania, respectively. The same alumina ALD precursors described above were used for the $\mathrm{Al}_{2} \mathrm{O}_{3}$ layers while tetrakis(dimethylamido)titanium(Iv) (TDMAT) and water were used for depositing the $\mathrm{TiO}_{2}$ films. Note that while the thick $\mathrm{Al}_{2} \mathrm{O}_{3}$ passivating front layer needs a $10 \mathrm{~min}$ annealing at $400{ }^{\circ} \mathrm{C}$, the annealing stage is not required for $\mathrm{Al}_{2} \mathrm{O}_{3} / \mathrm{TiO}_{2}$ stacks. Effective lifetime measurements were done by QSS-PC with a WCT-120 instrument (Sinton Consulting). The ESI (Fig. S6a $\dagger$ ) shows the main technological steps involved in the fabrication of the test structures to analyse surface passivation.

Contact resistance test samples were subjected to a cleaning sequence of RCA1/2 and a diluted HF (1\%) dip just before depositing the $\mathrm{Al}_{2} \mathrm{O}_{3} / \mathrm{TiO}_{2}$ stack by ALD with the same characteristics described above. An array of dot-patterned metal-pads with different diameters $(0.5,1,2$, and $4 \mathrm{~mm})$ was evaporated on the front of the devices by means of a metallic shadow mask while the rear side was fully covered with the same metal used at the front. All metals were thermally evaporated from pure source materials $>99.95 \%$ using a SQC-310 deposition controller (Sigma instruments). Metal films ( $\mathrm{Mg}, \mathrm{Al}$ or Ni) were $\sim 15 \mathrm{~nm}$ thick covered by a $\sim 150 \mathrm{~nm}$ thick Al layer. Evaporations were carried out in a vacuum chamber installed inside glovebox equipment $\left(\mathrm{O}_{2}<0.1 \mathrm{ppm}\right)$. The electrical measurements were performed using a four contact probe configuration by means of an $I-V$ tracer (Keithley 3601B) at room temperature. The ESI (Fig. S6b $\dagger$ ) shows the main technological steps involved in the fabrication of the contact resistance test structures.

The $\mathrm{Al}_{2} \mathrm{O}_{3} / \mathrm{TiO}_{2} / \mathrm{Mg}$ stack structure was studied by XPS using for the measurements a non-monochromatic Al-K $\alpha$ source $(1486.6 \mathrm{eV})$ at $3 \times 10^{-9} \mathrm{mbar}$ (SPECS, hemispherical energy analyser PHOIBOS 150). The thin films of $\mathrm{Al}_{2} \mathrm{O}_{3} / \mathrm{TiO}_{2}$ and $\mathrm{Al}_{2} \mathrm{O}_{3} /$ $\mathrm{TiO}_{2} / \mathrm{Mg}$ were deposited on polished c-Si wafers immediately after a HF (1\%) dip. High resolution images (HAADF-STEM) were acquired and both EDX and EELS chemical composition analyses were done using a Cs-corrected FEI Titan (60-300 kV) transmission electron microscope, equipped with a high brightness Schottky emitter source (X-FEG gun), a monochromator, and a Gatan $2 \mathrm{k} \times 2 \mathrm{k}$ CCD camera. The cross-section lamellas were prepared from contact resistance test samples, using a focused ion beam (FIB) lift-out technique. Before the FEI Titan analysis, the samples were subjected to an $\mathrm{O}_{2}$ plasma cleaning.

\section{Conflicts of interest}

There are no conflicts to declare.

\section{Acknowledgements}

This work has been supported partially by the Spanish Government under a FPU grant (FPU13/04381) and through projects ENE2016-78933-C4-1-R, TEC2014-59736-R, ENE201456237-C4-2-R and ENE2017-87671-C3-2-R. A part of the work is also supported by the project REFER COMRDI15-1-0036 funded by ACCIÓ and the European Regional Development Fund (FEDER). The authors wish to express their thanks to Dr R. Fernández-Pacheco and the Laboratorio de Microscopias Avanzadas (LMA-INA) facilities for SEM images and EELS/EDX analysis, as well as Dra M. Domínguez for her help and discussion about XPS measurements carried out at the Centre de Recerca en Ciència i Enginyeria Multiescala de Barcelona (CRCEMB).

\section{References}

1 U. Würfel, A. Cuevas and P. Würfel, IEEE Journal of Photovoltaics, 2015, 5, 461.

2 K. Yoshikawa, H. Kawasaki, W. Yoshida, T. Irie, K. Konishi, K. Nakano, T. Uto, D. Adachi, M. Kanematsu, H. Uzu and K. Yamamoto, Nat. Energy, 2017, 2, 17032.

3 I. Martín, J. M. López-González, M. Colina, A. Orpella and R. Alcubilla, Proceedings of the 28th European Photovoltaic Solar Energy Conference and Exhibition (EU PVSEC), Paris, France, 2013, p. 1311.

4 P. Ortega, G. López, D. Muñoz, I. Martín, C. Voz, C. Molpeceres and R. Alcubilla, Sol. Energy Mater. Sol. Cells, 2017, 169, 107.

5 M. T. Greiner, M. G. Helander, W. -M. Tang, Z. -B. Wang, J. Qiu and Z. -H. Lu, Nat. Mater., 2012, 11, 76.

6 J. Bullock, M. Hettick, J. Geissbühler, A. J. Ong, T. Allen, C. M. Sutter-Fella, T. Chen, H. Ota, E. W. Schaler, S. De Wolf, C. Ballif, A. Cuevas and A. Javey, Nat. Energy, 2016, 1, 15031.

7 J. P. Thomas, L. Zhao, D. McGillivray and K. T. Leung, J. Mater. Chem. A, 2014, 2, 2383.

8 F. Zhang, B. Sun, T. Song, X. Zhu and S. Lee, Chem. Mater., 2011, 23, 2084.

9 Y. Wan, C. Samundsett, J. Bullock, T. Allen, M. Hettick, D. Yan, P. Zheng, X. Zhang, J. Cui, J. McKeon, A. Javey and A. Cuevas, ACS Appl. Mater. Interfaces, 2016, 8, 14671.

10 Y. Zhang, W. Cui, Y. Zhu, F. Zu, L. Liao, S.-T. Lee and B. Sun, Energy Environ. Sci., 2015, 8, 297.

11 C. Battaglia, X. Yin, M. Zheng, I. D. Sharp, T. Chen, S. McDonnell, A. Azcatl, C. Carraro, B. Ma, R. Maboudian, R. M. Wallace and A. Javey, Nano Lett., 2014, 14, 967.

12 W. Wu, W. Lin, J. Bao, Z. Liu, B. Liu, K. Qiu, Y. Chen and H. Shen, RSC Adv., 2017, 7, 23851.

13 C. Battaglia, A. Cuevas and S. De Wolf, Energy Environ. Sci., 2016, 9, 1552. 
14 L. G. Gerling, S. Mahato, A. Morales-Vilches, G. Masmitjà, P. Ortega, C. Voz, R. Alcubilla and J. Puigdollers, Sol. Energy Mater. Sol. Cells, 2016, 145, 109.

15 Y. Wan, C. Samundsett, J. Bullock, M. Hettick, T. Allen, D. Yan, J. Peng, Y. Wu, J. Cui, A. Javey and A. Cuevas, Adv. Energy Mater., 2017, 7, 1601863.

16 S. Avasthi, W. E. McClain, G. Man, A. Kahn, J. Schwartz and J. C. Sturm, Appl. Phys. Lett., 2013, 102, 203901.

17 R. T. Tung, Appl. Phys. Rev., 2014, 1, 011304.

18 L. G. Gerling, C. Voz, R. Alcubilla and J. Puigdollers, J. Mater. Res., 2017, 32, 260.

19 G. Masmitjà, L. G. Gerling, P. Ortega, J. Puigdollers, I. Martín, C. Voz and R. Alcubilla, J. Mater. Chem. A, 2017, 5, 9182.

20 X. Yang, Q. Bi, H. Ali, K. Davis, W. V. Schoenfeld and K. Weber, Adv. Mater., 2016, 28, 5891.

21 B. Liao, B. Hoex, A. B. Aberle, D. Chi and C. S. Bhatia, Appl. Phys. Lett., 2014, 104, 253903.

22 K. A. Nagamatsu, S. Avasthi, G. Sahasrabudhe, G. Man, J. Jhaveri, A. H. Berg, J. Schwartz, A. Kahn, S. Wagner and L. C. Sturm, Appl. Phys. Lett., 2015, 106, 123906.

23 B. G. Lee, J. Skarp, V. Malinen, S. Li, S. Choi and H. M. Branz, Proceedings of the 38th IEEE Photovoltaic Specialists Conference (PVSC), Austin, TX, 2012, p. 1066.

24 N. Y. Garces, D. J. Meyer, V. D. Wheeler, Z. Liliental-Weber, D. K. Baskill and C. R. Eddy Jr, J. Vac. Sci. Technol., B: Nanotechnol. Microelectron.: Mater., Process., Meas., Phenom., 2014, 32, 03D101.

25 D. Suh, D.-Y. Choi and K. J. Weber, J. Appl. Phys., 2013, 114, 154107.

26 R. A. Sinton, A. Cuevas and M. Stuckings, Proceedings of the 25th IEEE Photovoltaic Specialists Conference (PVSC), Washington, DC, 1996, p. 457.

27 B. Hoex, S. B. S. Heil, E. Langereis, M. C. M. van de Sanden and W. M. M. Kessels, Appl. Phys. Lett., 2006, 89, 042112.
28 X. Yang, P. Zheng, Q. Bi and K. Weber, Sol. Energy Mater. Sol. Cells, 2016, 150, 32.

29 B. Hoex, J. J. H. Gielis, M. C. M. van de Sanden and W. M. M. Kessels, J. Appl. Phys., 2008, 104, 113703.

30 W.-C. Wang, M.-C. Tsai, J. Yang, C. Hsu and M.-J. Chen, ACS Appl. Mater. Interfaces, 2015, 7, 10228.

31 Y. Wan, C. Samundsett, D. Yan, T. Allen, J. Peng, J. Cui, X. Zhang, J. Bullock and A. Cuevas, Appl. Phys. Lett., 2016, 109, 113901.

32 ATLAS, http://www.silvaco.com/products/ device_simulation/atlas.html.

33 R. Brendel and R. Peibst, IEEE Journal of photovoltaics, 2016, 6, 1413.

34 M. T. Greiner and Z.-H. Lu, NPG Asia Mater., 2013, 5, e55.

35 B. Vincent Crist, XPS Handbook of the Elements and Native Oxides, XPS International Inc., 1999.

36 G. López, P. Ortega, C. Voz, I. Martín, M. Colina, A. B. Morales, A. Orpella and R. Alcubilla, Beilstein J. Nanotechnol., 2013, 4, 726.

37 C. Reichel, F. Granek, M. Hermle and S. W. Glunz, Progress in Photovoltaics: Research and Applications, 2013, vol. 21, p. 1063.

38 R. A. Sinton and A. Cuevas, Proceedings of the 16th European Photovoltaic Solar Energy Conference, Glasgow, UK, 2000, pp. 1-5.

39 M. A. Green, Solar Cells: Operating Principles, Technology and System Applications, University New South Wales, Kensington, F. S. W, Sydney, 1998, p. 96.

40 W. Kern, J. Electrochem. Soc., 1990, 137, 1887.

41 G. Masmitjà, P. Ortega, I. Martín, J. Pérez, G. López, E. Calle, L. G. Gerling, C. Voz and R. Alcubilla, Proceedings of the 11th Spanish Conference on Electron Devices (CDE), 2017, Barcelona, Spain, pp. 1-3. 